\title{
Life, Not Itself: Inanimacy and the Limits of Biology
}

\section{Citation}

Roosth, Sophia. 2014. "Life, Not Itself: Inanimacy and the Limits of Biology." Grey Room 57 (October): 56-81. doi:10.1162/grey_a_00156.

\section{Published Version}

doi:10.1162/GREY_a_00156

\section{Permanent link}

http://nrs.harvard.edu/urn-3:HUL.InstRepos:14023015

\section{Terms of Use}

This article was downloaded from Harvard University's DASH repository, and is made available under the terms and conditions applicable to Other Posted Material, as set forth at http:// nrs.harvard.edu/urn-3:HUL.InstRepos:dash.current.terms-of-use\#LAA

\section{Share Your Story}

The Harvard community has made this article openly available.

Please share how this access benefits you. Submit a story.

Accessibility 


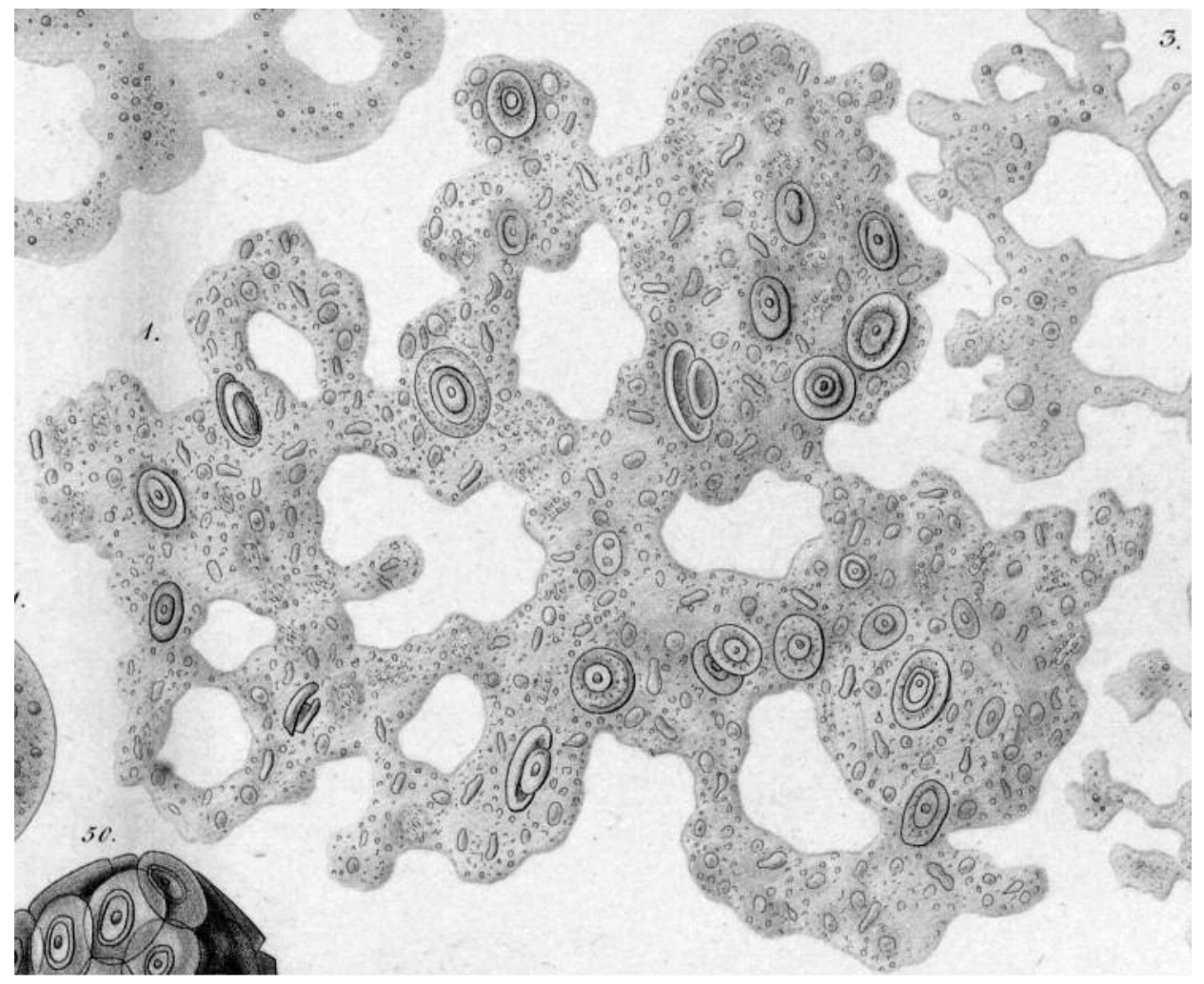

Ernst Haeckel. Bathybius

haeckelii. Plate 17 from "Beitrage

zur Plastidentheorie," Jenaische

Zeitschrift für Medizin und

Naturwissenschaft, vol. 5, 1870. 


\section{Life, Not Itself: Inanimacy and the Limits of Biology}

\section{SOPHIA ROOSTH}

\section{Origins: Mud and Slime}

Something that for three months had looked like a rock got up and moved about a foot, then settled down again and looked like a rock for three more months. Another rocklike thing sprouted an arm and waved it about for twelve hours, then remained motionless for the rest of the six months. Life proceeds without haste in the deep.

So the New York Times reported on time-lapse photographers seeking valuable minerals on the Pacific seafloor in $1977 .{ }^{1}$ How quickly must life proceed to count as life? What defines life when the animating processes that mark the living slow into imperceptibility, as life deanimates, slackening or pausing from the temporalities of biological phenomena into epochs geological? Such an uncanny discovery, made possible by the temporal disruptions of stop-motion photography, tests the limits of the organic and the inorganic, the living and the lifeless, in the silty beds of a salty sea.

The 1977 video of gesticulating rocks is the epistemological negative of an earlier blush-worthy scientific misstep: in 1868 Thomas Henry Huxley reported on

his microscopic investigations into some "sticky viscid" mud that had been dredged up by Captain Daymon of the H.M.S. Cyclops while sounding the depths of the Atlantic in preparation of laying telegraph cables. Huxley referred to the sea slime as an "Urschleim" and christened it Bathybius haeckelii in honor of his friend Ernst Haeckel, thinking that it was a new form of the "simple animated being" which Haeckel had described. ${ }^{2}$

The "excessively fine, light brown, muddy sediment” that Huxley identified as living and to which he appended Linnaean nomenclature "lived," with biologists" endorsement, just seven years. The substance was unique in the number of open questions in biology to which it (temporarily) provided a solution. Among them: the question of the first form of life on earth and the simplest matter common to all 
cells. ${ }^{3}$ The slime that Haeckel and Huxley recognized as the formless goo from which all living forms had spawned was later discredited as merely dredged deepsea mud. Whereas some rocklike life forms are deceptively still, mud sometimes deludes scientists into thinking it lively.

How is life defined when it is seemingly inert, no longer a verb but instead hardened substance in states of arrested suspension? Life at its most sluggish may appear to be mud, dust, powder, or rock. So in seeking life's limits, researchers at times have looked to those substances seemingly least biotic. They have also sought life in those places least likely to harbor it: the hot, acidic, and high-pressure environs miles beneath the sea; the arid desert; and the vacuum of outer space. ${ }^{4}$ I here trace the apparition in the history of biology of life latent, even dormant-paused to the point of near lifelessness, often by extreme cold or desiccation.

Since the mid-twentieth century, biologists have referred to this interrupted form of life as "cryptobiosis," but scientific inquiry into instances of paused or latent life has a long history that precedes this twentieth-century coinage. I here treat cryptobiosis as an "epistemic space," by which I mean "the broader realm in which a scientific concept takes shape" under multiple names, contexts, and modes of inquiry that "nevertheless elude full and final representation." ${ }^{5}$ Experimentalists from the seventeenth century to now have paused seeds, rotifers (microscopic zooplankton), and tardigrades (otherwise known as water bears or moss piglets), waiting months, years, or centuries to resuscitate and revive them. Such experiments prismatically refract the relation of life to animation, and of life to nonlife, as it has been asked about at different moments-with an eye to spontaneous generation, theological reflections upon mystical resurrection, boundaries between life and death, theoretical debates over metabolism versus structure as the definitional ground of life, as well as questions about the origins of life, its proper milieu, and its existence beyond earth.

In what follows, I offer a counterhistory of plumbing life's limits. Historians of the life sciences have observed that in seeking to generate theories of life, designers have time and again worked to simulate living processes in nonliving things. Artificial life and artificial intelligence are only the latest in a long history of efforts-including automatons, robots, homunculi, and software-to manufacture entities that bear those features most closely associated with life. Such objects do not point to an ahistorical definition of "life," but rather richly demonstrate what qualities practitioners have considered most lifelike in a given historical moment. Jessica Riskin parses these attributes most broadly as emergence and interaction, 
but they include, among other activities, growth, metabolism, locomotion, perception, responsiveness, and sentience (as well as breathing, sighing, praying, and playing music). Perhaps this is in part rooted in a lurking Platonism: substance is immaterial to an entity appearing "as if" alive; form is privileged over matter.

Diverse efforts in "artificial life" from antiquity to now are united in that they always assume lifelike processes simulated in abiotic media. As Riskin summarizes, artificial life "encompasses creatures made of wood, metal, stone, glass, papier mâché, electronic circuitry, silicon, and information." ${ }^{6}$ Yet, "one possible criterion of aliveness is simply to appear alive: an entity is alive if it provokes living beings to respond to it as such."7 Historians and philosophers of biology seeking to account for the techniques by which life is represented (rather than simulated or reproduced) have addressed media ranging from botanical atlases to microscopy to cinema, and much in between. ${ }^{8}$ Further, science studies scholars have demonstrated that representations of life rendered in media from film to software are often made lively precisely by being animated. ${ }^{9}$ This attention to artificial life rendered in abiotic media is not, however, the whole story.

In writing this alternative history, I look at artificial life's opposite: namely, inquiries into the limits of life that historically sought out precisely those entities that do not perform lively processes or trick us into thinking them lively. If anything, they trick us, at least for a time, into thinking them inorganic or inert. Such creatures behave in ways that resist assumptions about how life happens. These are organisms that, in periods of suspension, do not do anything-they do not grow, metabolize, move, perceive, or respond to their surrounding environment. Cryptobiosis and its historical precursors upend the historiographic assumption that theorizing life always relies on animation and vitality. Instead, the history I tell here suggests a mirror epistemology in which, in seeking life's limits, researchers chase after creatures that counterintuitively bear no signs of life.

Roving through this history of life suspended, my approach in what follows is itself cryptobiotic. That is, I span vast gaps in time, from the seventeenth century to now, pausing for decades, even centuries, in a state of suspension, only reanimating to tell my tale when the conditions are right. In making this argument from history, my approach is not chronological but synchronic and taxonomic. I proceed through a series of biological media, each of which incarnates a particular liminal vitality and announces a specific temporal problem inflecting theories of life. First, dirt and stone are petrified biological media, like fossils, that reveal the ways in which life was conceived of before sharp distinctions were made between the living 
and the nonliving and between life and death. Their temporality is static. Next, seeds and blossoms that remain dormant for decades, centuries, or millennia reveal long-held distinctions between life as patterned matter and life as an ongoing process. Their temporality is pauseable and retrospective, as they prove themselves lively only after they revive. A similar sort of temporality animates the third set of media I appraise: life in ice or crystal. Like seeds, frozen life troubles divisions between life as patterned matter and as process. Further, its temporality is actively and technically managed - that is, the time of life is rendered discontinuous when experimentalists join time to temperature. Next, in turning to life dried out into dust and ash, I ask how particular forms of suspended life-such as tardigrades and rotifers-suggest that the temporality of latent life is not only discontinuous but reversible.

Subsequently describing studies of life found in ancient rocks and seas, I show that cryptobiosis inflects problems of life's origins in dry or wet environments and in so doing problematizes what life becomes beyond its earthly milieu. Such temporalities are coeval: cryptobiotic creatures loop backward to stand in for the origins of all life on earth (and perhaps elsewhere). Finally, I conclude not with extraterrestrial origins but with unearthly destinations. Life suspended as a powder and let loose into the vacuum of space materializes and mobilizes theoretical biologists' exobiological theories about cryptobiosis. Simply put, if cryptobiosis suggests that earthly life may have extraterrestrial origins, exobiologists now actualize that theory by sending cryptobiotic organisms into space, where they become extraterrestrial. "Life," in each of these media, reticulates into multiple materialized theories of itself. ${ }^{10}$

Such a history is particularly relevant in the contemporary moment, when life scientists such as synthetic biologists inquire into what life is by manufacturing biotic media. Such new living entities, I argue elsewhere, are "theories, materialized." The biological features, theories, and limits researchers fasten upon are determined by their own experimental tactics, which they then identify with the creatures they themselves have made. ${ }^{11}$ In so doing, life scientists destabilize life as an object of investigation. The history of cryptobiosis offers a protracted view of how these triangulations between biological materials, biological media, and biological theories are not new. Rather, they are long-standing historical problemsbiological media are living substances embedding, shuffling, and sometimes upending regnant theories and scientific persuasions about what life is and what it is not. 
Athanasius Kircher. Stone with image of an owl. From Mundus Subterraneus, vol. 2, 1665.
FIGURA VOLUCRUM,

2uas Natura in lapidibus depinxit ex variis Mufeis decerpte,

Es aliunde tranfmiffe.

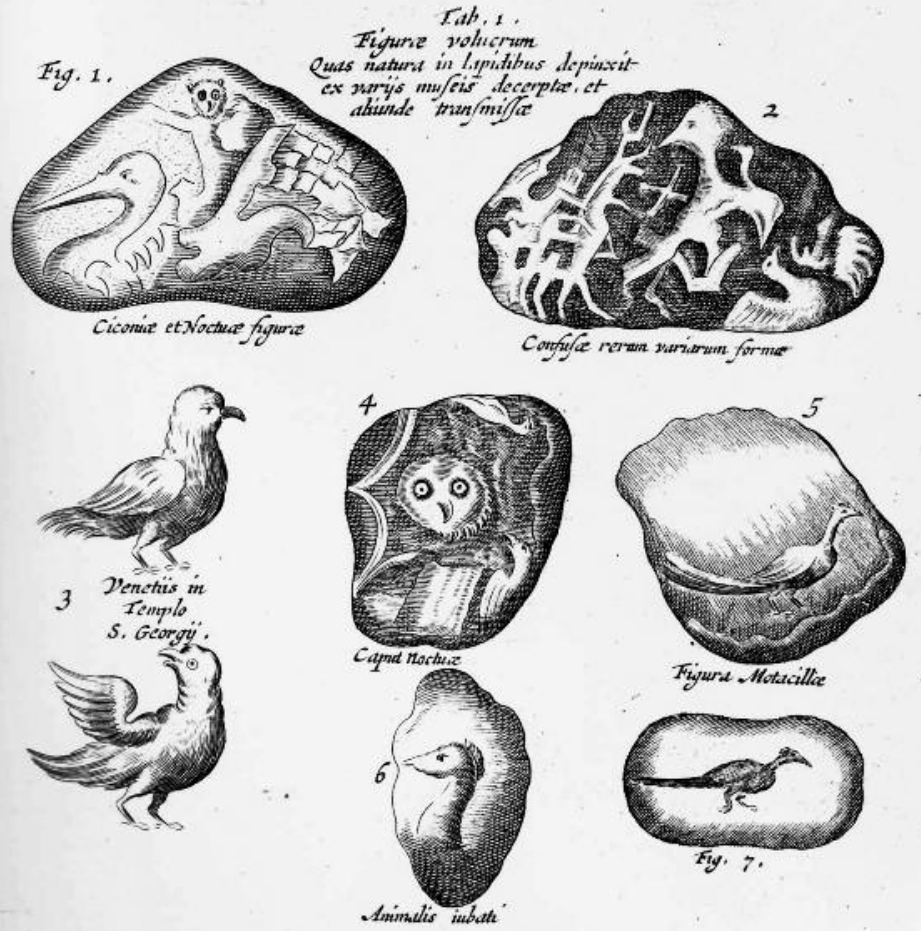

\section{Life Petrified: Dirt and Stone}

Before the nineteenth century, the life sciences had not yet carved the world up into the living and the nonlivingfollowing Michel Foucault, the epistemology of life was not yet conflated with living things under the umbrella of "life itself." Lifelike forms were readily apparent throughout the natural world, impressing themselves indiscriminately upon substances animal, vegetable, or mineral. ${ }^{12}$ In Mundus Subterraneus, Athanasius Kircher, like many naturalists of his time, carefully studied fossils in order to describe the natural ordering of the world. Kircher drew upon fossils as examples with which to critique alchemical explanations of the transmutation of substance while advocating a devout explanation for the existence of living form in the mineralogical world. ${ }^{13}$ He found, pressed in stone, imprints of plants and animals, as well as "complex religious scenes" such as "John the Baptist in his camel hair coat."14 In the fullness of time, life might be transformed into stone, Kircher suggested, by a "petrifying force.” Some fossils were once alive; others gain lifelike features through imprinting, casting, or the action of living things mobilizing rocks to generate living forms. Sometimes, he wrote, rocks take on such forms only in the active imaginations of their beholders. ${ }^{15}$ Yet for Kircher and his peers, no clear force distinguished life from nonlife-rather, animal, mineral, and vegetative forces impressed themselves on various substances, sometimes fluorescing or diminishing one into another.

Fifty years later, aided by microscopes, natural philosophers sought life invisible to the naked eye. The microscope promised mid-seventeenth century scholars answers to long-standing questions about life, including the vectors of contagion and debates over preformationism versus generation. Turning their eyes to biconvex lenses, they observed both the animate and inanimate material world. In 1702, Anton van Leeuwenhoek collected dirt and clay from house gutters, finding within animalcules that he rejuvenated with water droplets. Microscopist Henry Baker spied eel-worms in grains of blighted wheat, finding that their bodies "may be shrunk up, dried, and hardened," that "Life may be suspended and seemingly 
destroyed" and yet may be revived with the addition of water. He reckoned, "What Life really is, seems as much too subtile for our Understanding to conceive or define, as for our senses to discern and examine." ${ }^{16}$ For seventeenth-century microscopists, such investigations of the very small only bolstered mechanical philosophy, allowing them to offer mechanistic explanations for otherwise hermetic properties of the animate world. The living world, like the nonliving, was made up of so many tiny machines. ${ }^{17}$

Charles Dupaty, a French jurist and Enlightenment philosophe, visited the Grand Duke of Tuscany's curiosity cabinet in 1785, where he and Felice Fontana, the court physician, together revived desiccated eel-worms. Dupaty later recalled,

He only makes use of a drop of water. He takes care not to let it fall over these dust animals, for it might crush them in falling: he approaches by degrees the drop of water on the head of a needle, and by degrees the little animal is penetrated by its freshness. . . The animal receives life. ${ }^{18}$

Nonetheless, Fontana refused to report his experiments, fearing excommunication from the church for brushing against the mysteries of resurrection, eschatologically decreed to be solely within the powers of Christ. ${ }^{19}$

Animalcules in dirt, dried and hardened eel-worms, and dust animals touched by water-prior to the nineteenth century, no vital force apart from the divine was believed to animate creatures. The operating distinction was not between the organic and the inorganic but between the living and the dead. Despite the sway of mechanical philosophy, theological associations impregnated such thinking. Caroline Walker Bynum reminds us of altogether other sorts of animated, and therefore sanctified, stones. To the amazement of fourteenth- and fifteenth-century Catholics, frescoes, relics, and statues of saints would, at times, sweat, weep, bleed, lactate, and wink. The faithful venerated these things as holy because they wavered between stillness and animation-when immobile, they transcended the mortal realm by resisting changeability and decay; when they miraculously leaked fluids, they revealed themselves to be alive, dynamic, and divine. Neither stony immobility nor dynamism was sufficient to constitute such potent miracles-rather, in these cases "matter contradicts matter" by wavering between the two. "Transformation miracles were moments in which matter contradicted itself. But it could do so only in material ways. Hence, if matter transcended its own ordinary changeability by denying decay, it could do so, it seemed, only by yet another change. Such extraordinary change could, however, last only a moment." ${ }^{20}$ Leeuwenhoek's microscopical inves- 
tigations and Dupaty's revived eel-worms were the first of many studies of life, continuing to this day, in which the problematic of living substance-its generation and its driving forces-echoes the vexing matter with holy matter in the late Middle Ages. Matter is recognized as alive by reference to moments in which it contradicts itself: it is pauseable and interruptible, often immobile but always potentially changeable and therefore vital.

\section{Life Dormant: Seed and Blossom}

Botanical investigations into growing seeds long dormant also troubled boundaries between life and death. They posed life as inert patterned matter that could be halted, existing in a frozen state of potential reanimation. The "sacred lotus" (Nelumbo nucifera) waited a millennium, nestled in the peat of an ancient Manchurian lakebed. Robert Brown, a paleobotanist and first Keeper of Botany at the British Museum, successfully germinated desiccated water lily seeds in 1850 after they had been stored away in a box for 150 years. ${ }^{21}$ His careful experimental attentiveness to Nelumbo was characteristic of Victorian botany of the time, in which the verdant wealth of the empire was amassed in the gardens and herbaria of Britain as both a scientific resource and a spectacle of colonial might. The upper limits of seed dormancy were also, in the mid-nineteenth century, of increasing interest to Charles Darwin, as seed viability could impact how widely a plant might disperse. Brown's feat inspired physician and conservationist Joseph Le Conte to ask, "What is Life?" He mused that this question is "agitated" by "cases of dormant life, as in seeds kept for years, perhaps for centuries . . . in which under favorable conditions active life is revived . . . life is supposed to be feeble, but not extinct." 22 Le Conte concluded that when "life seems to spring spontaneously from dead matter," biologists must conclude that the difference between living and dead protoplasm is merely "a difference in molecular arrangement-a difference in allotropic condition." ${ }^{23}$ When the processes of life cease, all that is left to designate dormant life as living is its material organization.

Physiologist Paul Becquerel conducted similar studies in the early twentieth century. He froze and desiccated seeds, bacteria, moss, and infusoria for varying lengths of time, up to eighty-seven years, before stimulating them to revive. Becquerel termed this phenomenon "latent life" (at other times "suspended life"). ${ }^{24}$ In part, Becquerel's work sought to refute panspermia, the hypothesis that life could have arrived at earth from other planets, a theory that had been promoted by some French physiologists since the 1870s and the upshot of Félix Pouchet and Louis Pasteur's 


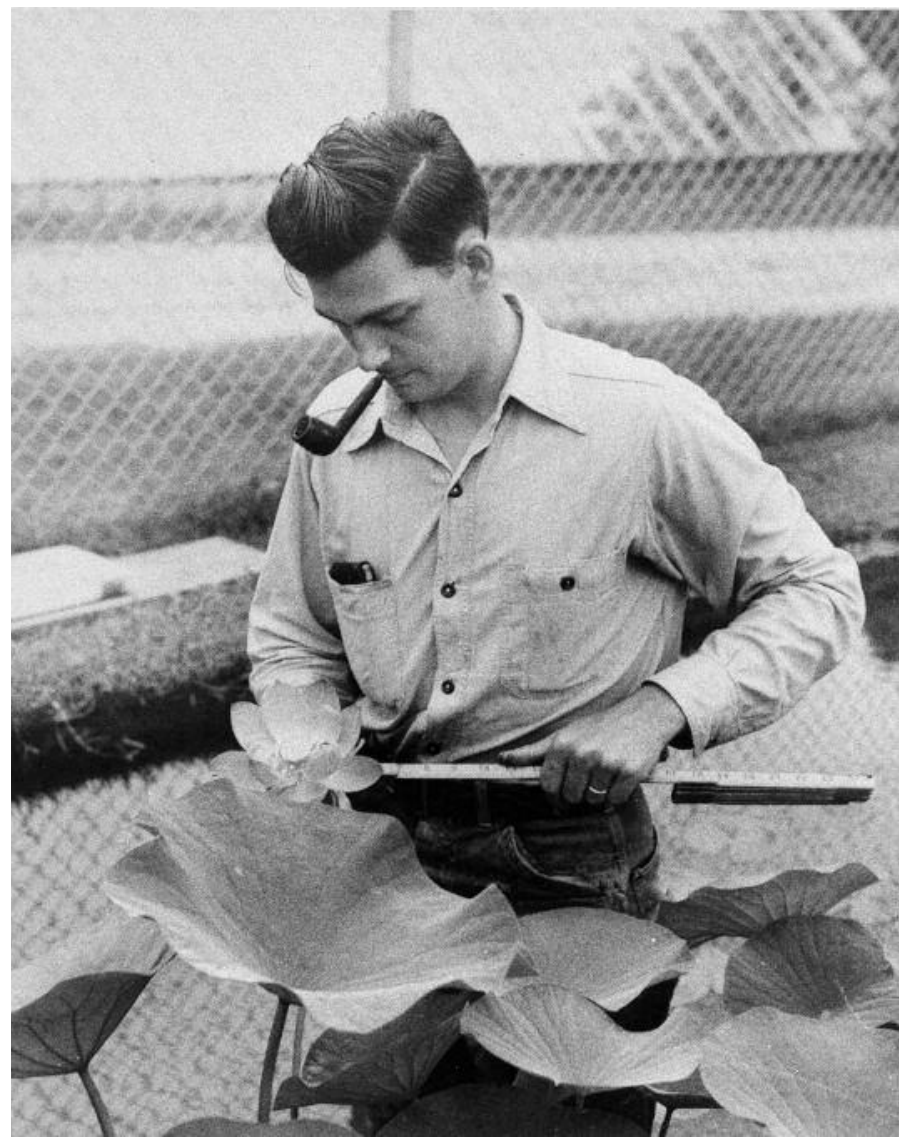
further late-nineteenth- and early-twentieth-century botanists pushed back life's limits, deferring liveliness to the moment after latency, when vitality once again inspires previously seemingly dead, or at least inert, matter. Worrying the distinctions between life and nonlife, living and dead, latently living things, following such techniques, are abductively identified according to their potential future life or are recognized in retrospect only after they revive.

Fast-forward forty years, when seeds of the sacred lotus, then estimated to be between 400 and 50,000 years old, flowered abundantly in Kew Gardens and Berkeley, California. ${ }^{26}$ The riotous bloom made headlines, and newspapers breathlessly reported on the seeds' germination, sprouting, and flowering. For ecologists and biologists at midcentury, cryptobiosis gave the lie to the notion that life is continuous and that the cessation of living processes leads inevitably to death. Cryptobiosis, biologists felt, offered "a unique opportunity to study the discontinuity of life processes." ${ }^{27}$ Seeds reported as potentially Paleolithic could be coaxed once again into abundant and inflorescent life. Such thinking upsets the trajectory by which life hurtles toward inevitable death, reorienting biology as a discontinuous phenomenon in which life is interruptible and death reversible.

\section{Life Frozen: Ice and Crystal}

To halt life and plumb problems of biological chronology, experimentalists have long frozen living substance, both literally (by lowering temperatures) and figuratively (stopping life "dead" in its tracks). Such experiments have served multiple ends, from questioning the theory of panspermia to developing technologies with which to bank living substances for future experimentation and use (in laboratories, 
as well as in animal husbandry, human reproductive technologies, and cryogenics). Cryptobiosis joins cryobiology, rendering biological suspension and resurrection a frosty enterprise. Natural philosophers and scientists have long sought to use extreme cold to pause and reanimate life, beginning at least with Robert Boyle's seventeenth-century experiments freezing ox brains. In the first decades of the twentieth century, biologists learned to freeze and thaw microbes and spermatozoa; in the 1950s some experimented with reanimating hamsters. The cultivation of tis-

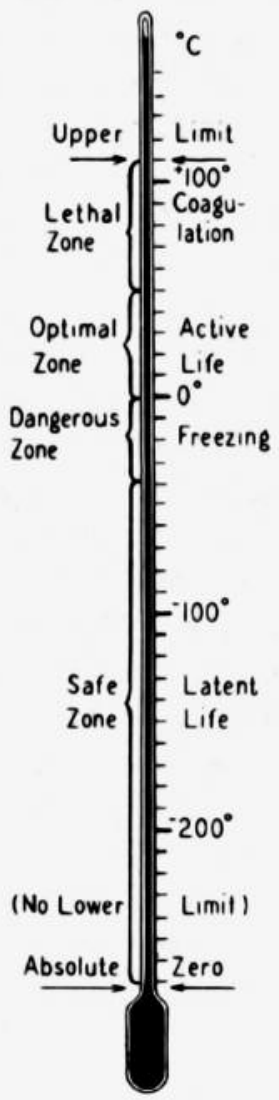
sue culture and cell lines, made possible by careful calibrations of temperature, made cellular materials some of the most useful and temporally extendable and suspendable living tools of experimental biosciences by midcentury. ${ }^{28}$ In the 1960s Robert Ettinger built on earlier research freezing human tissues to pioneer cryogenics, freezing dead persons' brains in hopes of their eventual reanimation and subsequent immortality. ${ }^{29}$

At midcentury, freezing experiments forwarded theories of cryptobiosis, joining time to temperature, so that the slowing of living processes gestured toward the pausing and resumption of biological temporalities. Yet experimentalists disagreed about the meaning of controlling biological suspension and revival via low temperatures. For example, in the 1930s N.I. Kalabuchow froze insects and mammals and then reanimated them, arguing that what he termed Winterschlaf ("winter sleep," or hibernation) suggests that "the theory of anabiosis, that is the supposition of the possibility of resuscitation of an organism after the complete cessation of its life processes, is not correct. Life is an uninterrupted process." ${ }^{30}$

Or is it? In Life and Death at Low Temperatures, a survey of experimental cryobiology inspired by the studies of Paul Becquerel, Basile Luyet and Sister Marie Pierre Gehenio posit differently:

An organism which resists extreme cold behaves like a watch which, though well wound, is stopped by some braking mechanism. This watch is in perfect condition as to its constructional features and it will start of its own accord as soon as the brake is removed. .. . This state of affairs is consistent with the hypothesis that the force which controls the vital activities requires a special 
structure of matter, and that, when that structure is destroyed, the organism is dead, while, when the structure is maintained, the protoplasm is alive, though it might not be active. ${ }^{31}$

David Keilin would later reach similar conclusions. In a 1958 lecture before the Royal Society of London, Keilin coined a new term for an old scientific concept. He "propose[d] the term cryptobiosis, that is, latent life, for the state of an organism when it shows no visible signs of life and when its metabolic activity becomes hardly measurable, or comes reversibly to a standstill.”32 Keilin's coinage united a swarm of words biologists had previously used to denote inactivity, among them anabiosis, abiosis, hypometabolism, hibernation, diapause, hypobiosis. Extreme environmental conditions, including "loss of water, lowering of temperature, absence of oxygen and high salt concentration" can induce a suspension of biological activity. ${ }^{33}$ This is life concealed or not apparent-cryptobiosis is, properly speaking, hidden life.

In this respect, the term is a product of its time-at midcentury, life had become a coding problem, as cryptologists joined with cyberneticians seeking to "crack" the "genetic code." 34 A cold biology crystallized in the Cold War. A postwar problem, latent life became a cipher to be decrypted, a pregnant pause awaiting reanimation. Keilin claimed, "no doubt that, at very low temperatures, all biochemical and physiological reactions, in other words, all processes of life, can be reversibly suspended for considerable periods of time.” ${ }^{35}$ For Keilin, cryptobiosis raised the question of "whether life under certain conditions may be a discontinuous process." ${ }^{36} \mathrm{He}$ concluded that cryptobiotic organisms, despite being static, are alive because they maintain life's "structure," if not its processes. As lively activity decelerates to imperceptibility, rendered discontinuous and inactive via the action of freezing or drying, biologists understood the difference between life and death as merely structural. Here is an answer not simply to the question "What is life?" but also "What is alive?" Following on midcentury cryobiological definitions of life as patterned structure, and of midcentury cybernetic theories of life as information (another sort of pattern, one unleashed from material substance), one might think of such frozen living fluids not as life hidden in stone, rock, or powder but as life, crystallized.

In her history of tissue culture, Hannah Landecker describes how cryobiology produces "all the disassembled generations, the novel simultaneities, the gaps of time between death of one generation and birth of another with a suspension of continuity between them-all of these deeply unsettling temporal disruptions., ${ }^{37}$ But 
such "disruptions," while revising what counts as biological, entail a further reworking of "life." As biological processes cease in extreme cold, biologists redefine life not as a process but as organized structure. Attending to creatures suspendable and revivable reorients definitions of life away from the continuous unspooling of living phenomena and toward life as patterned matter: "it seems to be necessary where cryptobiotes are concerned," reflect biologists John Crowe and Alan Cooper Jr., "to define life and death in terms other than the presence or absence of metabolism. We believe that among cryptobiotes life should be defined in terms of the continuity of organized structure."38

Yair Neuman argues this point even more strongly in positing that " "life' is in the organization and that in a very deep sense, organization is the cause in the living matter." 39 Here, however, organization is more than structure-it is a "cause," something that impels future action. Akin to potential energy, organized structure, by this logic, operates as a coiled spring, a sort of vital principle that inheres in cryptobiotes and can trigger future vital dynamism. If the temporalities of life may experimentally and forcefully be discontinued, then potential life, for such twentieth-century researchers and theoretical biologists, burrows in continuous patterned structure. The midcentury definition of cryptobiosis as a paused living physical arrangement was in many respects the reverse of cybernetic theoretical biology of the time, which treated life as a self-organized complex system, regardless of its materiality. A "flow of energy" was what "distinguish[ed] such patterns from, for instance, the formation of oil drops or snowflakes." 40

\section{Life Suspended: Dust and Ash}

Asking "Exactly 'What Is Life?'” Gerald Feinberg and Robert Shapiro arrive at similar conclusions. They broadcast the answer to their question in their article's subtitle: "It's the Most Interesting Form of Organization of Matter on Earth." Dating this paper as an artifact of the 1980s, they begin their ruminations with Pet Rocks, the toy craze of the late 1970s in which rocks were shipped in boxes with airholes, accompanied by a manual on the "Care and Training of Your Pet Rock." ${ }^{41}$ Asking how to differentiate between life and "rocks, sand, and other nonliving things," they pose the tardigrade, a microscopic (250-800 micrometer) eight-legged aquatic extremophile, as a bellwether:

Tardigrades can be dried out and stored in a bottle on a shelf for many years, to all intents like the lifeless ashes of Great-uncle Lemuel. But add water 
to instant tardigrade, and the animals will be restored to their normal state and scamper merrily about, no worse for their long, dry nap. Is tardigrade powder alive? ${ }^{42}$

Such a question challenges assumptions that life and its processes unspool in a continuous and irreversible sequence.

The tardigrade was first discovered and given its Latinate name (meaning "slow stepper") in 1776 by Lazzaro Spallanzani, the naturalist best known for hammering a nail into the coffin of spontaneous generation. The putative life, death, and revival of tardigrades remained an open question for over a century thereafter. One Victorian, for example, wrote about tardigrades in Charles Dickens's weekly journal All the Year Round. Some may believe, he or she commented, that

after being killed they can be brought to life again, and that not once, but after several killings; that they may be exposed to the heat of boiling water; that they may be revivified after the completest desiccation, after they have been brought to and kept for an unlimited time in a state of dryness in comparison with which the dryness of a mummy or a stockfish is humidity itself; that they are capable of an actual and material resurrection, not with a renovated or glorified body, but with the same old worn-out, martyred body, in which they gave up the ghost. ${ }^{43}$

Resurrection here, as in the case of Fontana's eel-worms, references Christian eschatology (think also of the venerated statues and relics of the late Middle Ages) organisms' bodies are either "martyred" or "glorified" in their renewal. The author disputes such reports, however, on the grounds that he or she had abortively attempted to revive desiccated rotifers in his or her drawing room: "While there was life, there was hope; but when once the patients were dead, they were dead as door nails." 44 "Resuscitating Animals" can be read as part of a larger conversation among Victorian authors about biological descent and modification, natural selection, and spontaneous generation, as well as debates between vitalists and mechanists over the relation of biological form to process. ${ }^{45}$ In rejecting the "resurrectionists" as misguided or deluded, the author reasserts life as arising once (and only once) and modifying continuously, thereby subscribing to the Darwinist camp. Darwin's detractors, in particular the terminal supporters of spontaneous generation, posited that life might have arisen multiple times, and the strange behavior of suspended rotifers could have offered experimental evidence to bolster such thinking. ${ }^{46}$ 


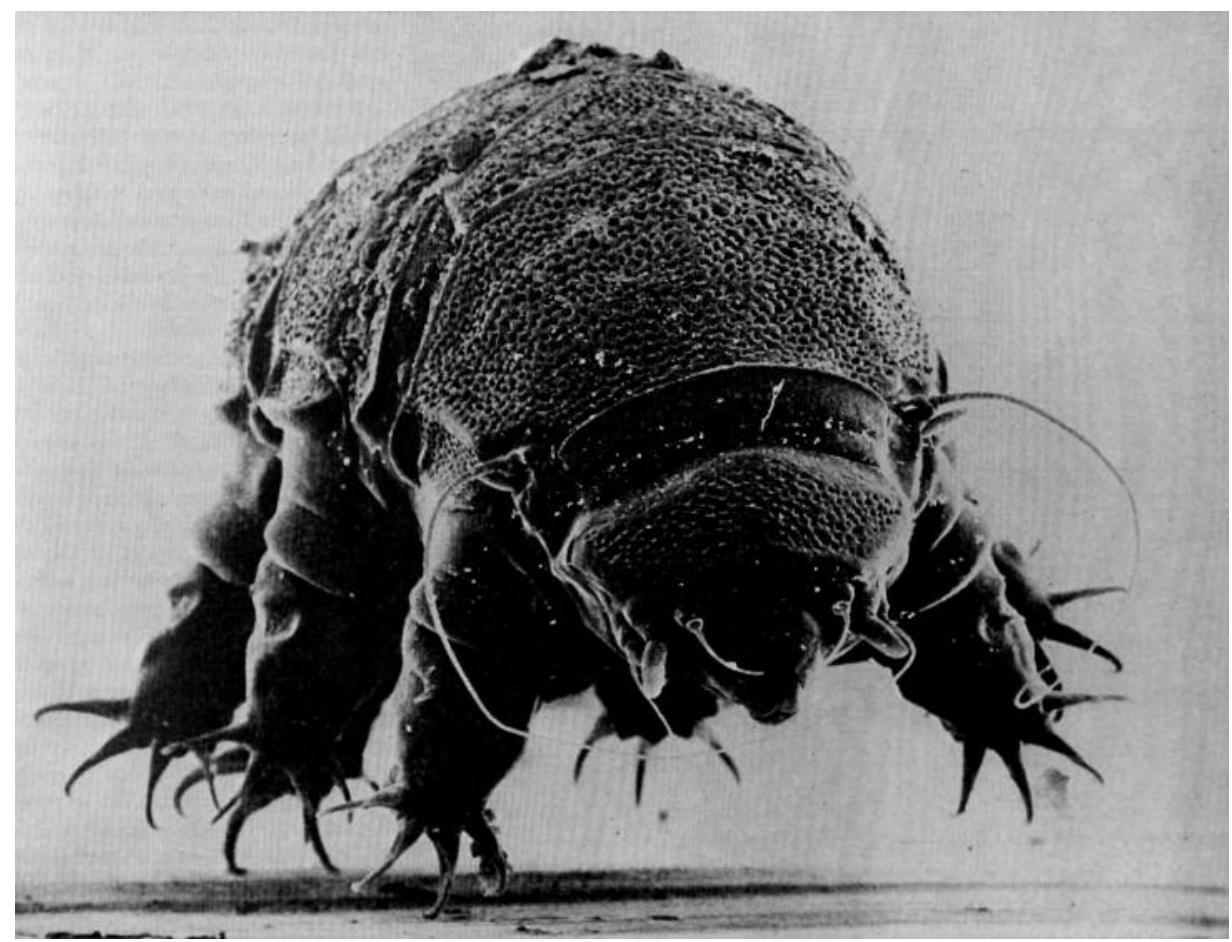

Yet by the twentieth century the curious capacities of tardigrades were no longer challenged by biologists. Theoretical ecologists now declare, "Some organisms more than others challenge our traditional concepts of life. Tardigrades definitely belong to this group" because they "defy some of the standard definitions of what being alive entails." ${ }^{47}$ Biologists have subjected tardigrades to a volley of environmental abuses, heating them to 151 degrees Celsius, freezing them to temperatures approaching absolute zero, assaulting them with noxious chemicals (sulfuric acid, ethanol, and methyl bromide), and exposing them for days to vacuums, high pressure, and over 570,000 roentgens of radiation. ${ }^{48}$ The lifespan of tardigrades is flexible in its interruptibility: biologists estimate that if a tardigrade never enters cryptobiosis, it lives less than a year, but if it cycles through cryptobiotic and dynamic states, it can live upward of sixty years.

What, then, is life when it does not maintain itself by the metabolic intake and exhaustion of energy, the synthesis of organic molecules (carbohydrates, lipids, proteins, nucleic acids), and the subsequent disposal of waste? Some contemporary biologists conclude that if metabolism is one of the processes that specifies life, then its technical suspension, even during cryptobiosis, must necessarily be a state of death:

Since metabolism is a defining characteristic of life one can argue that cryptobiosis is a kind of temporary death. ... To exclude miraculous stories, as those described in the Bible and the New Testament, a dead organism cannot be revived. Death is irreversible and it is the final station of the organism's journey along the arrow of time. However, an organism that is in a state of cryptobiosis is in a unique state that is somehow a state of a potentially reversible death. ${ }^{49}$

Edging between life and death, biologists now recognize cryptobiosis as a liminal state: "there are three states of biological organization: alive; dead; and cryptobiotic." 50 A question then arises: if death is indeed reversible, and a cryptobiotic 
tardigrade is, at least for the time being, dead, how does it emerge from death to rejoin the living? What jumpstarts metabolism in a static composition of living matter burrowed within its environment?

This question has been asked before of creatures in states of suspended animation, most notably by theoretical biologist Jakob von Uexküll, who pondered the tick:

At the Zoological Institute in Rostock, they kept ticks alive that had gone hungry for eighteen years. ... We shall therefore assume that the tick is, during its waiting period, in a state similar to sleep. ... But time stands still in the tick's waiting period not just for hours but for years, and it starts again only when the signal "butyric acid" awakens the tick to renewed activity. ${ }^{51}$

For von Uexküll, the tick demonstrates that "without a living subject, there can be no time.”52 The tick’s “sleep” recalls tardigrades" "long, dry nap.” 53 Philosopher of biology Georges Canguilhem chose Uexküll's tick as a specimen for his intervention into physico-chemical reductionist theories of biology. While Canguilhem wrests the milieu from a vestigial mechanism by emphasizing the active, sensorial, and spatial interplay of an organism and its environment, the milieu is notably, not merely spatial but also temporal. "Along with Buffon, Lamarck said: time and favorable circumstances constitute the living little by little. Uexküll reverses the relationship and says: time and favorable circumstances exist only in relation to a specific living thing." 54

But what is the time specific to a cryptobiotic organism like the tick or the tardigrade? Toward answering this same question, Yair Neuman reimagines C.H. Waddington's epigenetic landscape, in which gene regulation shapes development. The tardigrade, Neuman writes, does not suit Waddington's diagram. Instead, "the visual representation which is perfectly fit to describe the bootstrapping activity of the tardigrade is the Klein bottle, a higher dimensional topological version of the Möbius strip." ${ }_{55}$ If the tardigrade can catapult itself from a state of temporary "death" back into life, then life and death are no longer orientable categories but instead operate on a continuum traversable in a manner akin to the surface-interior of a Klein bottle. Adding cryptobiosis as a third category mediating between life and nonlife, theoretical biologists suppose tardigrades to be material emblems of the reversible relays between life and death, even living instantiations of nonlinear temporalities, such that the discontinuous chronologies of cryptobiotes loop life and death. 


\section{Life Transported: Rock and Sea}

Abstracting beyond the lives and deaths of individual animals, cryptobiosis not only generates theories about biological temporality but also about the improbable milieus where life might thrive and the origins of all life from abiotic matter, both on this planet and beyond. Cryptobiosis again stimulated biologists' imaginations in the thick of experiments in the 1950s and 1960s, most famously in the Miller-Urey experiment, which chemically simulated the environment of early earth in order to demonstrate the abiogenic origins of life. During this time, some biologists speculated that cryptobiosis is a sign of organisms' unearthliness and contended that cryptobiotes are therefore evidence of panspermia. "Since dried rotifers, tardigrades, and nematodes conceivably survive conditions of outer space, May et al. (1964) hypothesized that the ancestors of these animals might have been of extraterrestrial origin." ${ }^{56}$ George Gaylord Simpson, vertebrate paleontologist at Harvard's Museum of Comparative Zoology, was doubtful: while surmising that panspermia was improbable, he admitted that perhaps "once life had arisen somewhere, organisms in a state of cryptobiosis might have spread by 'cosmozoan' transport from one planet to another." 57

Tardigrades and other cryptobiotic organisms had found themselves caught up in a contest between a new crop of exobiologists and their skeptics. After the launch of Sputnik in 1957, the newly formed National Aeronautics and Space Administration (NASA) recruited prominent biologists such as Joshua Lederberg to a Committee on Biological Research, whose charter was to seek life on other planets. ${ }^{58}$ Rather than recognizing tardigrades as innately and indelibly earthlings, given that their cryptobiotic capacities allow them to inhabit nearly every ecological niche on earth, astrobiologists took their ability to arrest themselves as fundamentally alien in origin. In so doing, they sited them as both progenitors of all life on earth and as hailing from other worlds. The incredibility of earthbound cryptobiosis underwrote exobiological hypotheses of interplanetary origins, ones some biologists self-consciously identified as "conceivabl[e]," but others blasted as "curious" and "extremely improbable." 59

Perhaps, some biologists mused, cryptobiosis demonstrates that the origin of life need not be tethered to water-life may have spawned on dry land, not the ocean. Theoretical biologists have wondered whether "the capacity to tolerate total dehydration at developmental temperatures [is] a primitive feature of protoplasm." 60 Protoplasm, the primordial viscous fluid that nineteenth-century biologists supposed manifested all subsequent forms of life, shares conceptual ground with 
Lorenz Oken's Urschleim (the "sea-mucous" from which all living things spawned), as well as subsequent developments in cell theory. ${ }^{61}$ Protoplasm retains this connotation of coagulated marine ooze and therefore seems incompatible with "the capacity to tolerate total dehydration." 62 Yet, etymologically, protoplasm hews closer to first form than to primitive fluid, and it is this meaning to which twentieth-century theoretical biologists adhered when they conjectured that life emerged from stone rather than sea.

H.E. Hinton, for example, wondered whether on early earth, isolated puddles of water occasionally dried up and then pooled again, creating conditions necessary for the development of all life on earth via cryptobiosis: "The occasional desiccation of the pools on the land might have led to the selection of living entities which could survive anhydrobiotic conditions." ${ }^{63}$ Central here is not simply the reconception of life as structure rather than process but the reorientation of life's proper milieu as dry, not wet: "the organism is reduced to a purely morphological state, the successful maintenance of which does not require interactions between cells or between constituents of cells but only requires that certain spatial interactions be preserved." ${ }^{64}$ Under such conditions, Hinton and Crowe argued, the evolution of life proceeded not in a step-wise manner but by the spatial accumulation of dry particles in a pattern that instantaneously generated life when saturated. ${ }^{65}$ The definition of life is here decoupled from scientific and popular associations with water and even liquidity as its necessary condition, suggesting instead, counterintuitively, that life arose in locales least suited to living: "Cryptobiosis demands reexamination of another common belief: that water is essential to life."66

\section{Destinations: Powder and Vacuum}

In May 2012, NASA teamed with the Italian Space Agency to realize earlier theoretical biologists' speculations as to the extraterrestrial origins of tardigrades by launching 120 desiccated specimens of two species of tardigrades into open space aboard the space shuttle Endeavour. This experiment followed upon research performed five years prior in which tardigrades collected from hazel leaf litter in Modena flew aboard the Russian spacecraft FOTON-M3. They were launched from Kazakhstan on a Soyuz rocket and wheeled for twelve days in low earth orbit. ${ }^{67}$ During their trip on Endeavour, the powdered tardigrades were bombarded with cosmic radiation, withstanding low temperatures and microgravity. Upon returning to earth and being rehydrated, the tardigrades' survival rates matched those of the control populations that had marked time in a Modenese laboratory. Some space 


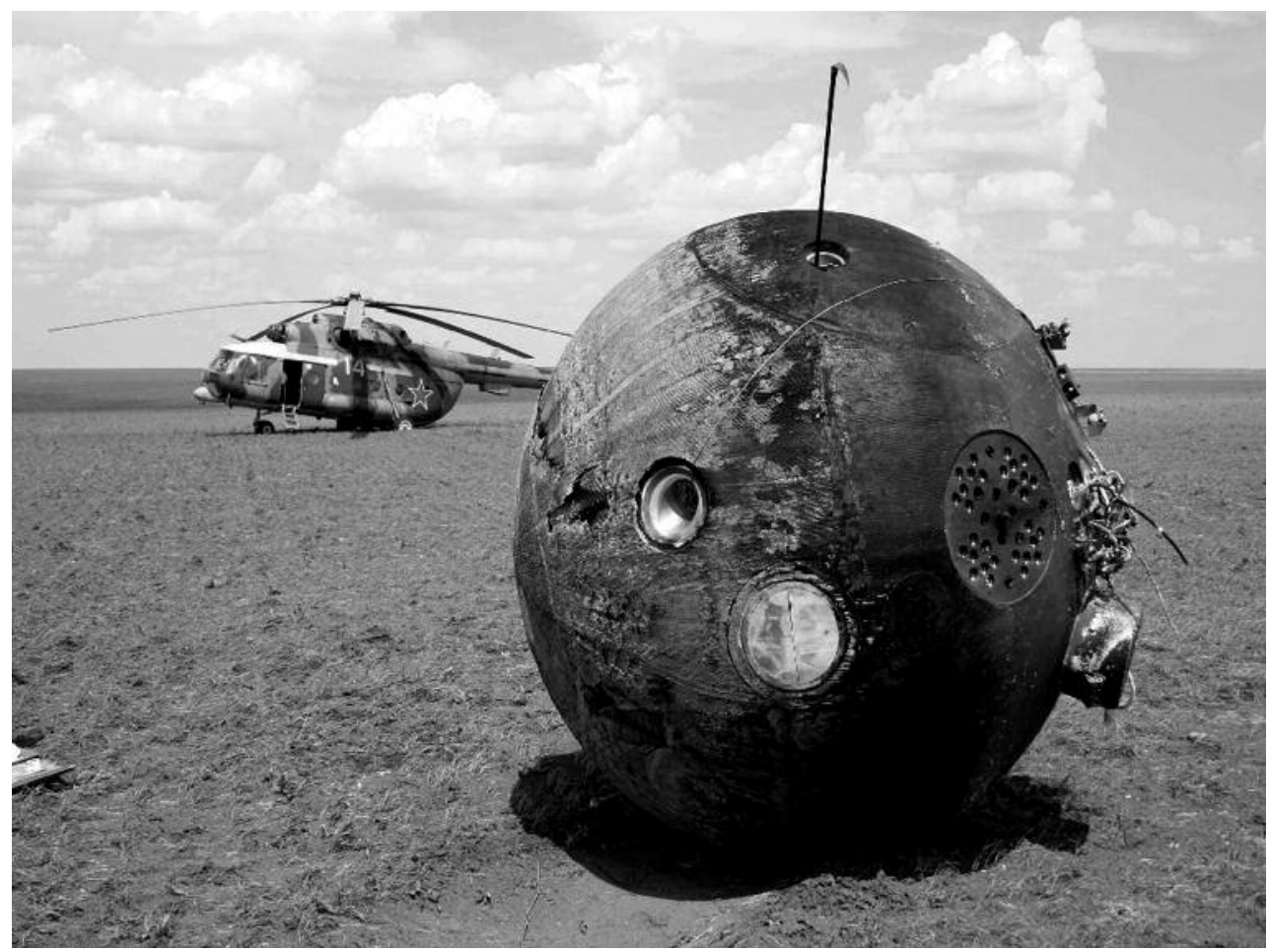

travelers, researchers discovered, had laid eggs in space and hatched normal spawn. Exobiologists evaluating these interstellar experiments concluded, "flight experiments with multicellular organisms are of great interest for estimating the existence of complex life forms on other planets, as well as the existence of simple single-cell life-forms. Such investigation might provide new insights into the probabilities of interplanetary transfer and existence of extraterrestrial multicellular organisms." ${ }^{68}$ If rotifers can mystically be resurrected from dust, and a sacred lotus can blossom after millennia, then, following such theological narratives, the tardigrade lately has been raptured into the heavens. Biologists have long been arguing whether cryptobiosis is a biological capacity that proves theories ranging from preformationism to abiogenesis to natural selection to spontaneous generation to panspermia. Yet the colony of tardigrades spawning eggs in space neither proved nor disproved a biological theory - rather, the experiment was itself an act of materializing exobiological theories about life, its capacities, and its limits.

In a more popular register, on March 6, 2013, NASA's "Astronomy Picture of the Day" featured a color-enhanced electron micrograph of a tardigrade captioned,

Is this an alien? Probably not, but of all the animals on Earth, the tardigrade might be the best candidate. ... Some of these miniature water-bears almost became extraterrestrials recently when they were launched toward to $[$ sic $]$ the Martian moon Phobos on board the Russian mission Fobos-Grunt, but stayed terrestrial when a rocket failed and the capsule remained in Earth orbit. ${ }^{69}$

From playthings in Dickens's drawing room to mascots for a speculatively dry origin of life to tokens of panspermia, tardigrades are now model organisms for exobiology. They allow biologists to think about what life is when it delaminates from its earthly milieu.

Back to rocks. Having begun with a deep-sea rock "sprout[ing] an arm," I end with a similarly eldritch stone, which recently photo-bombed a scientific image in 
an unlikely locale and left some scratching their heads over its potential liveliness. On January 16, 2014, NASA scientists admitted bafflement when a rock that did not appear in a recent photograph captured by the Mars Exploration Rover Opportunity appeared in a subsequent image captured twelve Martian days later. ${ }^{70}$ Though NASA scientists speculate that the rock was either moved by the rover itself or was flung there by a meteorite impact, others are unconvinced. On January 27, selfdescribed astrobiologist Rhawn Joseph filed a petition for a writ of mandamus against NASA with the U.S. District Court in San Francisco. Demanding that further images be released to the public, he writes that he "immediately recognized" the rock in question as "resembling a mushroom-like fungus, a composite organism consisting of colonies of lichen and cyanobacteria, and which on Earth is known as Apothecium."71 As evidence of its liveliness, Joseph claims that multiple images document the rock growing and sprouting fruiting bodies. Anthropologist Hugh Raffles invites us to observe how "archaeopoetry" can "reconstruct stone life," thereby "bringing life to and from the stone."72 Yet what ambiguous life is not only brought "to and from" stone but also is in and of stone? Once again, ambiguous and disputable life manifests in hardened stone, stone that suddenly appears, or moves, or does something unusual (for a stone, that is). Encountered by scientists in remote, far-flung, and ostensibly lifeless locales, the stone must now be reckoned with as something either definitively on one side or the other of the boundary between life and nonlife, as demonstrated by criteria including pattern and process, terrestrial and unearthly, wet and dry, animate and immobile.

But what unites Athanasius Kircher's seventeenth-century compendium of lifelike fossils with today's powdered tardigrades hurtling through space (and, for that matter, weirdly composite Martian stone-fungi)? As natural philosophers, biologists, and allied experimentalists have sought various answers to the question "What is life?" they often have looked to that which seemingly is not life, and not just by trying to build performatively lifelike entities out of inorganic materials. They have asked whether living things might arise from, live in, inform, or be generated out of stone, dust, mud, rock, and powder. In his history of animated inorganic things, Spyros Papapetros traces the ways in which animation infuses vitality into things not properly alive-modern art, technology, architecture. ${ }^{73}$ While what I have presented here is an obverse of Papapetros's project-a history of organic inanimacythe temporalities in which things move or do not move, and the speed at which they do or do not do so, is itself a principle by which things transition from organic to inorganic, from mineral to animal or vegetal. A rock that waves an arm, 
however slowly, is transubstantiated by this act from the inorganic realm into the organic one, while organisms stilled in states of suspended animation are classed as only problematically alive, not dead, yet nonetheless pervaded by a potent and vital potentiality.

To offer a highly speculative taxonomy of these abiotic substrates, I might begin by suggesting that prior to nineteenth-century definitions of "life" as something epistemically distinct from the nonliving world, stones-in the form of fossils imprinted by living form-demonstrated indistinctions between things that were once organic, things that inhere traces of the organic, and things that merely appear as if organic. Dust was the religiously inflected substance mysteriously transubstantiated into life by the addition of water droplets, as in the seventeenth-century experiments of natural philosophers like Baker and Dupaty. Mud represented the putative origins of life, as theorized by Victorian biologists foiled by sea sediment. By the mid-twentieth century, theoretical biologists referenced rocks as alternate places from which life might have originated as patterned matter, in the absence of metabolic processes or a biopoietic "primordial soup." Powder, in the form of desiccated cryptobiotes, now gestures toward potential life, suspended as organized living matter in a reversible state between life and death. Such powders, in the hands of exobiologists, promise life arriving at or returning to earth from origins or destinations unknown.

The life forms I have turned to in telling this history are not representations of life, images, icons, indices, or signs meant to typify, simulate, or designate life in modes naturalistic or mimetic. Instead, they are material instantiations that reference themselves as extreme, problematic, or limit cases of what counts as life: life slower than we expect, at times discontinuous or paused; life in substances classed as abiotic (rock, dust, powder); or life found in (and sometimes destined for) the unlikeliest places. They are, in short, things, things that by dint of their materiality tell us what, at various moments, has counted as life. ${ }^{74}$ Teeming in what is arguably the deepest crevasse of metaphysical divides, that which is situated between life and nonlife, the paradoxical, chimeric life forms I here track-petrified, frozen, dried, powdered, irradiated, and dormant for millennia-are self-referential material apparatuses manifesting theories of what life is, what it is not, and what lies in between. 


\section{Notes}

This paper originated while thinking with members of Biogroop: Stefan Helmreich, Natasha Myers, and Michael Rossi. I thank them for years of lively conversations about life. I am also grateful to Elaine Freedgood, Jeremy Greene, Emily Riehl, Hillel Schwartz, and Alma Steingart, who offered keen criticism and insightful feedback on multiple versions of this piece. John Drew, Harriet Ritvo, and Sharon Weltman helped track down obscure references, and Brad Bolman was a valiant research assistant. Finally, I thank Lucia Allais for shepherding this article into print.

1. William Wertenbaker, "Mining the Wealth of the Ocean Deep: Multinational Companies Are Gearing Up to Scour the Floor for Mineral Wealth,” New York Times, 17 July 1977.

2. Dani Hallet, "Vital Matters: Prep Work towards a Negative Image of a Keyword Entry" (final paper, History and Anthropology of Biology and Medicine, Harvard University Department of the History of Science, Spring 2013). See also Philip F. Rehbock, "Huxley, Haeckel, and the Oceanographers: The Case of Bathybius Haeckelii,” Isis 66, no. 4 (1975): 504-533.

3. Rehbock, "Huxley, Haeckel, and the Oceanographers," 505.

4. Stefan Helmreich has written about scientists' efforts to discover life in such unlikely locales. See Stefan Helmreich, “The Signature of Life: Designing the Astrobiological Imagination,” Grey Room 23 (Spring 2006): 66-95; and Stefan Helmreich, Alien Ocean: An Anthropology of Marine Microbiology and the Limits of Life (Berkeley and Los Angeles: University of California Press, 2009).

5. Staffan Müller-Wille and Hans-Jörg Rheinberger, A Cultural History of Heredity (Chicago: University of Chicago Press, 2012), xi-xii.

6. Jessica Riskin, Genesis Redux: Essays in the History and Philosophy of Artificial Life (Chicago: University of Chicago Press, 2007), 14.

7. Riskin, Genesis Redux, 26.

8. Lisa Cartwright, Screening the Body: Tracing Medicine’s Visual Culture (Minneapolis: University of Minnesota Press, 1995); Lorraine Daston and Peter Galison, Objectivity (New York: Zone Books, 2007); Joseph Dumit, Picturing Personhood: Brain Scans and Biomedical Identity (Princeton, NJ: Princeton University Press, 2003); Hannah Landecker, "Microcinematography and the History of Science and Film,” Isis 97, no. 1 (March 2006): 121-132; Hannah Landecker, "Cellular Features: Microcinematography and Film Theory,” Critical Inquiry 31, no. 4 (June 2005): 903-937; Natasha Myers, "Molecular Embodiments and the Body-Work of Modeling in Protein Crystallography," Social Studies of Science 38, no. 2 (April 2008): 163-199; Brian W. Ogilvie, The Science of Describing: Natural History in Renaissance Europe (Chicago: University of Chicago Press, 2008); Nicolas Rasmussen, Picture Control: The Electron Microscope and the Transformation of Biology in America, 1940-1960 (Stanford, CA: Stanford University Press, 1997); and Anne Secord, "Botany on a Plate: Pleasure and the Power of Pictures in Promoting Early Nineteenth-Century Scientific Knowledge,” Isis 93, no. 1 (March 2002): 28-57.

9. Stefan Helmreich, Silicon Second Nature: Culturing Artificial Life in a Digital World (Berkeley and Los Angeles: University of California Press, 1998); and Christopher Kelty and Hannah Landecker, “A Theory of Animation: Cells, L-systems, and Film,” Grey Room 17 (Fall 2004): 30-63. 
10. In a similar register, Stefan Helmreich concludes that in recent decades, "Life and theory now double or shadow one another more densely than ever. . . . Life and theory, wavering, gesture toward indeterminacy about... how life forms and forms of life form and deform in the shadow that has overtaken life after theory." Stefan Helmreich, "What Was Life? Answers from Three Limit Biologies," Critical Inquiry 37, no. 4 (2011): 695-696.

11. Sophia Roosth, Synthetic: How Life Got Made (Chicago: University of Chicago Press, forthcoming).

12. Michel Foucault, The Order of Things: An Archaeology of the Human Sciences (New York: Pantheon Books, 1971), 127-128.

13. Athanasius Kircher, Mundus Subterraneus, in XII libros digestus; quo divinum subterrestris mundi opificium, mira ergasteriorum naturæ in eo distributio, verbo pantámorphou Protei regnum, universæ denique naturæ majestas (Amsterdam: Joannem Janssonium, 1665).

14. Paula Findlen, Athanasius Kircher: The Last Man Who Knew Everything (New York: Routledge, 2004), 210-211.

15. In the early twentieth century, biologists again looked for life nestled in rocks, reporting on the presence of living microbes in "crushed amber, meteorites, quartz, basalts" as well as "pre-Cambrian and other rocks." David Keilin, "The Leeuwenhoek Lecture: The Problem of Anabiosis or Latent Life: History and Current Concept," Proceedings of the Royal Society of London: Series B, Biological Sciences 150, no. 939 (17 March 1959): 171.

16. Henry Baker, Employment for the Microscope. In Two Parts: Likewise a Description of the Microscope Used in These Experiments-An Examination of Salts and Saline Substances, Their Amazing Configurations and Crystals, as Formed under the Eye of the Observer. An Account of Various Animalcules Never Before Described (R. Dodsley, 1753), 256; emphasis in original.

17. Catherine Wilson, The Invisible World: Early Modern Philosophy and the Invention of the Microscope (Princeton, NJ: Princeton University Press, 1995).

18. Charles-Marguerite-Jean-Baptiste Mercier Dupaty, Travels through Italy: In a Series of Letters; Written in the Year 1785 (G.G.J. and J. Robinson, 1788), Letter 33, pp. 100-104, quoted in Keilin, "The Leeuwenhoek Lecture."

19. Dupaty, Travels through Italy. I here limit mystical resurrection to Christian theology because Fontana feared Catholic excommunication. I do not suggest that traditions of resurrection are limited to Christianity, as they also circulate in Islamic, Buddhist, Judaic, and Voudou belief and folklore, among others.

20. Caroline Walker Bynum, Christian Materiality: An Essay on Religion in Late Medieval Europe (New York: Zone Books, 2011), 285.

21. Brown is perhaps best known as the scientist who discovered the phenomenon subsequently named for him: in 1827 he observed Brownian motion of Clarkia pulchella (pinkfairy) pollen grains in solution under a microscope.

22. Joseph Le Conte, “What Is Life?” Science 13, no. 338 (21 June 1901): 991.

23. Le Conte, "What Is Life?" 991; emphasis in original.

24. Paul Becquerel, "Recherches sur la vie latente des graines," in Thèse de doctorat-Sciences naturelles-Faculté des sciences de Paris 1265 (Masson, 1907); "Recherches expérimentales sur la vie 
latente des spores des Mucorinées et des Ascomycètes aux basses températures de l'hydrogène liquide," Comptes rendus de l'Académie des sciences, Paris 150 (1910): 1437-1439; "Action abiotique des rayons ultraviolets sur les spores sèches aux basses températures et l'origine cosmique de la vie," Comptes rendus de l'Académie des sciences, Paris 151 (1910): 86-88; "La vie latente des graines de pollen dans le vide à $271^{\circ} \mathrm{C}$. au-dessous de zéro," Comptes rendus de l'Académie des sciences, Paris 188 (1929): 1308-1310; "La vie latente des spores des Fougèares dans le vide aux basses températures de l'hélium liquide," Comptes rendus de l'Académie des sciences, Paris 190 (1930): 1134-1136; and "La vie latente des spores des Mousses aux basses températures," Comptes rendus de l'Académie des sciences, Paris 194 (1932): 1378-1380. While Spyros Papapetros credits Becquerel with coining the term latent life, it is often attributed to experimental physiologist Claude Bernard in his 1878 Phenomena of Life Common to Animals and Plants, where it denotes "chemical indifference" induced by low temperatures. See Robert L. Perlman, “The Concept of the Organism in Physiology,” Theory in Biosciences 119, no. 3-4 (1 November 2000): 174-186. Eight years earlier, however, eugenicist Francis Galton referenced "latent life" without defining the term. Francis Galton, Hereditary Genius: An Inquiry into Its Laws and Consequences (D. Appleton, 1870). Latent life was simultaneously revived in 1910 and 1911 by biologists Alexis Carrel and Stéphane Leduc. Leduc describes "latent life" as akin to "a machine that has been stopped, but which retains its form and substance unaltered, and may be started again whenever the obstacle to its progress is removed." Stéphane Leduc, The Mechanism of Life (William Heinemann, 1911), 7. In reporting on grafts of arterial tissue, Alexis Carrel explains, "a tissue is in latent life when its metabolism becomes so slight that it cannot be detected, and also when its metabolism is completely suspended. Latent life means, therefore, two different conditions, unmanifested actual life and potential life." Alexis Carrel, "Latent Life of Arteries," Journal of Experimental Medicine 12, no. 4 (1910): 460. The phrase was again resurrected by entomologist David Keilin in 1958 to denote resuscitating organisms kept in suspension by desiccation or low temperatures. Keilin, "The Leeuwenhoek Lecture."

25. Spyros Papapetros, On the Animation of the Inorganic: Art, Architecture, and the Extension of Life (Chicago: University of Chicago Press, 2012), 119.

26. Carbon dating later aged the seeds at $1040( \pm 200)$ years. Willard F. Libby, "Radiocarbon Dates, II,” Science 114, no. 2960 (21 September 1951): 291-296.

27. John H. Crowe, "Anhydrobiosis: An Unsolved Problem," American Naturalist 105, no. 946 (1971): 571.

28. Hannah Landecker, Culturing Life: How Cells Became Technologies (Cambridge, MA: Harvard University Press, 2007).

29. Bronwyn Parry, "Technologies of Immortality: The Brain on Ice," Studies in History and Philosophy of Science Part C: Studies in History and Philosophy of Biological and Biomedical Sciences 35, no. 2 (June 2004): 391-413.

30. N.I. Kalabuchow, "Anabiose bei Wirbeltieren und Insekten bei Temperaturen unter $0^{\circ}$," Zool. Jahrb., Abt., Allgem. Zool. Physiol. Tiere 55 (1935): 63, quoted in Keilin, “The Leeuwenhoek Lecture," 177; emphasis in original.

31. Basile Joseph Luyet and Marie Pierre Gehenio, Life and Death at Low Temperatures (Normandy, 
MO: Biodynamica, 1940), 255; emphasis in original.

32. Keilin, "The Leeuwenhoek Lecture," 166; emphasis in original.

33. Keilin, "The Leeuwenhoek Lecture," 167.

34. Lily Kay, Who Wrote the Book of Life? A History of the Genetic Code (Stanford, CA: Stanford University Press, 2000).

35. Keilin, "The Leeuwenhoek Lecture," 180.

36. Keilin, "The Leeuwenhoek Lecture," 164.

37. Landecker, Culturing Life, 227-228.

38. John H. Crowe and Alan F. Cooper Jr., “Cryptobiosis,” Scientific American 225, no. 6 (1971): 36.

39. Yair Neuman, "Cryptobiosis: A New Theoretical Perspective," Progress in Biophysics and Molecular Biology 92 (2006): 263.

40. Evelyn Fox Keller, "Organisms, Machines, and Thunderstorms: A History of Self-Organization, Part Two: Complexity, Emergence, and Stable Attractors," Historical Studies in the Natural Sciences 39, no. 1 (February 2009): 11.

41. More than a peculiar consumer craze, Pet Rocks suggest that the affects attached to living things may sometimes (even if in contrived and flippant ways) be extended to inanimate objects. "The commercially successful fad for buying and caring for ... pet rocks (pet rocks sold in the hundreds of thousands during the mid-1970s) suggests how the institution of pethood might enable us to toe the line not only between human animal beings and nonhuman animal beings but also between animate and nonanimate beings.” Marc Shell, “The Family Pet,” Representations, no. 15 (1986): 151n88.

42. Gerald Feinberg and Robert Shapiro, "A Definition Is Debated: Exactly What Is 'Life'? ... It's the Most Interesting Form of Organization of Matter on Earth—'The Activity of a Biosphere,"” Science Digest 88 (August 1980): 52.

43. Anonymous, "Resuscitating Animals," All the Year Round 2, no. 43 (18 February 1860): 387-388.

44. Anonymous, "Resuscitating Animals," 387-388. One candidate for author of this essay is George Henry Lewes, live-in lover of George Eliot, who the same year published an essay in Cornhill Magazine reporting on experiments desiccating and reviving rotifers: "The lifeless oval has become a living animal! You have assisted at a resuscitation, not from death by drowning, but by drying: The animal has been drowned into life!" The essay nonetheless ends skeptical about resuscitation: "the rotifer once dried is dead, and dead forever." George Henry Lewes, Studies in Animal Life (London: Smith, Elder and Co. 1862), 63, 68. Reprinted from George Henry Lewes, "Studies in Animal Life Ch. 3," Cornhill Magazine 1 (1860): 283-295.

45. Nicola Bown, "What the Alligator Didn't Know: Natural Selection and Love in Our Mutual Friend," 19: Interdisciplinary Studies in the Long Nineteenth Century, no. 10 (28 April 2010). See also James Edgar Strick, Sparks of Life: Darwinism and the Victorian Debates over Spontaneous Generation (Cambridge, MA: Harvard University Press, 2002).

46. Strick, Sparks of Life.

47. K. Ingemar Jönsson and Roberto Bertolani, "Facts and Fiction about Long-Term Survival in Tardigrades," Journal of Zoology 255 (2001): 121; and Crowe and Cooper, “Cryptobiosis,” 30. 
48. Lorena Rebecchi et al., "Resistance of the Anhydrobiotic Eutardigrade Paramacrobiotus Richtersi to Space Flight (LIFE-TARSE Mission on Foton-M3)," Journal of Zoological Systematics and Evolutionary Research 49 (Suppl. 1) (2011): 98.

49. Neuman, "Cryptobiosis," 260; emphasis in original.

50. James S. Clegg, "Cryptobiosis-A Peculiar State of Biological Organization," Comparative Biochemistry and Physiology Part B 128 (2001): 615.

51. Jakob von Uexküll, A Foray into the Worlds of Animals and Humans with a Theory of Meaning (1934; Minneapolis: University of Minnesota Press, 2010), 52.

52. Uexküll, A Foray into the Worlds of Animals and Humans, 52.

53. Feinberg and Shapiro, "A Definition Is Debated."

54. Georges Canguilhem, “The Living and Its Milieu,” trans. John Savage, Grey Room, no. 3 (Spring 2001): 20 .

55. Neuman, "Cryptobiosis," 266.

56. Crowe, "Anhydrobiosis,” 570. See also R.M. May, M. Maria, and J. Guimard, "Actions différentielles des rayons X et ultraviolets sur le tardigrade Macrobiotus areolatus, à l'état actif et desséché," Bulletin biologique de la France et de la Belgique 98 (1964): 349-367.

57. George Gaylord Simpson, "The Nonprevalence of Humanoids," Science 143, no. 3608 (21 February 1964): 772.

58. Audra J. Wolfe, "Germs in Space: Joshua Lederberg, Exobiology, and the Public Imagination, 1958-1964," Isis 93, no. 2 (1 June 2002): 183-205.

59. Crowe, "Anhydrobiosis”; and Simpson, “The Nonprevalence of Humanoids," 772.

60. H.E. Hinton and A.E. Needham, "Reversible Suspension of Metabolism and the Origin of Life [and Contribution to the Discussion]," Proceedings of the Royal Society of London: Series B, Biological Sciences 171, no. 1022 (August 1968): 53. See also Crowe, "Anhydrobiosis"; and H.E. Hinton, "Cryptobiosis in the Larva of Polypedilum Vanderplanki (Chironomidae)," Journal of Insect Physiology 5, no. 3-4 (December 1960): 286-300.

61. Lorenz Oken, Elements of Physiophilosophy (1809), trans. Alfred Tulk (London: Ray Society, 1847).

62. Hinton and Needham, "Reversible Suspension of Metabolism," 51.

63. Crowe, "Anhydrobiosis," 570.

64. Hinton and Needham, "Reversible Suspension of Metabolism," 43.

65. Vociferously disputing this possibility, J.D. Bernal posited that life could not possibly arise from "rapidly drying up cracks in rocks." J.D. Bernal, The Origin of Life (Cleveland: World Publishing Company, 1967), 110.

66. Hinton and Needham, "Reversible Suspension of Metabolism," 43.

67. Rebecchi et al., "Resistance of the Anhydrobiotic Eutardigrade Paramacrobiotus Richtersi to Space Flight."

68. Daiki D. Horikawa, "The Tardigrade Ramazzottius Varieornatus as a Model Animal for Astrobiological Studies," Biological Sciences in Space 22, no. 3 (2008): 93. Why the second usage of life form in this quotation is hyphenated while the first is not is unclear. For one theory of why 
hyphens sometimes disappear from this compound word, consult Stefan Helmreich and Sophia Roosth, "Life Forms: A Keyword Entry," Representations 112, no. 1 (1 November 2010): 27-53.

69. "Tardigrade in Moss," Astronomy Picture of the Day [blog], 6 March 2013, http://apod.nasa.gov/ apod/ap130306.html.

70. Meeri Kim, “Mars Rover Opportunity Finds Mysterious 'Jelly Doughnut Rock' on the Red Planet," Washington Post, 24 January 2014.

71. Rhawn Joseph v. National Aeronautics and Space Administration (NASA), In Re Rhawn Joseph's Petition for a Writ of Mandamus Compelling NASA to Perform a Duty to Thoroughly Scientifically Examine and Investigate a Putative Biological Organism on Mars Identified/Discovered by Petitioner and Referred to by NASA as: "Unlike Anything We Have Seen Before," 27 January 2014, U.S. District Court, Northern District of California.

72. Hugh Raffles, "Stone" (colloquium lecture, Harvard University Department of the History of Science, 17 April 2013).

73. Not-life is animated, Papapetros argues, in two modes: "The first animated type is material: it represents changes and transformations in the substance of objects, transitions from the organic to the inorganic, from animal to vegetal to mineral, and so on. The second form of animation is temporal: it describes rebirths, survivals, renewals, and anachronisms." Papapetros, On the Animation of the Inorganic, $\mathrm{x}$.

74. In this regard, I follow Lorraine Daston's call to grapple with "things that talk," those material "nodes at which matter and meaning intersect. Entities that lie precisely at the fault line of a great metaphysical divide tend to appear paradoxical for just that reason." Lorraine Daston, Things That Talk: Object Lessons from Art and Science (New York: Zone Books, 2003), 16. 